\title{
CYP3A5 Substrate
}

National Cancer Institute

\section{Source}

National Cancer Institute. CYP3A5 Substrate. NCI Thesaurus. Code C155916.

Any substance that is metabolized by cytochrome P450 3A5. 